\title{
Ksiądz profesor Jerzy Bajda. Profesor w środowisku naukowym Instytutu Studiów nad Rodziną ATK-UKSW
}

Wstęp

Ksiądz prof. Jerzy Bajda pracę naukową rozpoczął wcześnie w środowisku tarnowskim i krakowskim, następnie kontynuował ją na Wydziale Teologicznym ATK. Od 1981 roku pracował na stanowisku docenta w Instytucie Studiów nad Rodziną ATK w Łomiankach, a od 1993 roku na stanowisku profesora nadzwyczajnego ATK, będąc kierownikiem Katedry Teologii Moralnej Małżeństwa i Rodziny w Zakładzie Teologii Systematycznej. Był wybitnym członkiem Rady Naukowej Instytutu Studiów nad Rodziną. Był również członkiem Rady Naukowej Instytutu Jana Pawła II KUL. Także Polskie Stowarzyszenie Moralistów w ostatnich latach bardzo go szanowało i często zapraszało na spotkania.

Miałem szczęście być słuchaczem wykładów ks. prof. Jerzego Bajdy jako ksiądz student od roku
- Wstęp

- Działalność naukowa

- Dorobek naukowy

- Sylwetka profesora

- Zakończenie 
akademickiego 1985/86 oraz napisałem pod jego kierunkiem pracę magisterską. Następnie, gdy w roku 1992 dołączyłem do zespołu pracowników naukowych Instytutu Studiów nad Rodziną, mogłem już jako asystent, a potem adiunkt uczestniczyć w radach naukowych i sympozjach, podczas których podziwiałem niezwykłą głębię refleksji teologicznej Księdza Profesora. Uczyłem się od niego wnikliwego spojrzenia na rzeczywistość rodziny w wymiarach zarówno nadprzyrodzonych, jak i naturalnych. Budowałem się postawą Księdza Profesora Jerzego w jego codziennym życiu na uczelni, w relacjach z pracownikami, a jeszcze bardziej w jego otwartości na studentów.

\section{Działalność naukowa}

W działalności naukowo-badawczej Księdza Profesora przeważały dwa nurty. Pierwszy z nich obejmował podstawy powołania chrześcijańskiego ${ }^{1}$. Wokół tej kategorii rozwijał teologię małżeństwa i rodziny przez wszystkie lata pracy w Instytucie Studiów nad Rodziną, owocnie współpracując w tej kwestii z jego założycielem ks. bp. prof. Kazimierzem Majdańskim, który kładł mocny nacisk na konieczność tworzenia syntezy teologii małżeństwa i rodziny, opartej na teologicznej koncepcji powołania. Jednak refleksję naukową na ten temat ks. prof. Jerzy Bajda rozpoczął w kontakcie z teologicznym środowiskiem krakowskim.

Istotną inspiracją poszukiwań Księdza Profesora była myśl Soboru Watykańskiego II oraz encyklika papieża Pawła VI Humanae vitae, wokół której skupiała się posoborowa dyskusja etyczna i pastoralna, jak również bardzo bogate nauczanie w tej dziedzinie Papieża Rodzin, św. Jana Pawła II².

Jako przykład głębi spojrzenia Księdza Profesora na powołanie człowieka zacytuję jego odkrywczą myśl:

Sobór zwięźle stwierdza, że ludzie, jako stworzeni, „powołani są do jednego i tego samego celu, to jest do Boga samego" (KDK 24). Łacińskie vocantur mogłoby być przetłumaczone przez „powoływani są, gdyż oryginalny tekst wskazuje na trwały i nieustannie teraźniejszy charakter tego

1 Owocem tych badań była praca habilitacyjna: Powołanie chrześcijańskie jako zasada teologii moralnej.

2 Por. J. Bajda, Powołanie małżeństwa i rodziny, Łomianki 2010, s. 11. 
aktu „powoływania”. Akt powołania przenika się tu z aktem obdarowywania istnieniem, czyli z aktem stwórczym, dzięki któremu człowiek po prostu ,jest”, istnieje, z całą prawdą bytu, określającą jego tożsamość. Człowiek jest powoływany tym samym aktem, którym jest stworzony i ukonstytuowany w tożsamości swej istoty. Akt stworzenia nie jest „wcześniejszy" niż akt powołania, choć mamy skłonność podkreślać, że powołanie jest logicznie późniejsze. Jednak w zamyśle Bożym logicznie „wcześniejsze” jest to, co zawiera się w akcie Przedwiecznej Miłości i dlatego nie ma żadnej sprzeczności w przyjęciu tezy, że powołanie (jako akt Boga) wyprzedza w pewien sposób stworzenie. Taką właśnie perspektywę zdaje się przed nami odsłaniać List do Efezjan, gdzie czytamy, że Bóg (w Chrystusie) „wybrał nas przed założeniem świata” (Ef 1, 4). Powołanie jest owocem przedwiecznego wybrania, które nie tyle czasowo, ile „metafizycznie" wyprzedza istnienie świata stworzonego. Dlatego stworzenie człowieka dokonuje się już w perspektywie powołania i owego przeznaczenia, o którym mowa dalej w Liście: „Z miłości przeznaczył nas dla siebie jako przybranych synów przez Jezusa Chrystusa" (Ef 1, 4). A więc zanim zaistnieliśmy, już Bóg Ojciec umiłował nas w swoim Synu, przeznaczył dla Niego i powołał, abyśmy byli dziećmi Bożymi przez uczestnictwo w Jedynym Synu Bożym³ ${ }^{3}$.

Kolejny nurt refleksji naukowo-badawczej Księdza Profesora dotyczył kwestii teologicznomoralnych małżeństwa i rodziny. Pojawił się on tuż po zakończeniu II Soboru Watykańskiego, w związku z pracami prowadzonymi w Krakowie z inspiracji kard. Karola Wojtyły, w zespole, który oprócz ks. prof. Jerzego Bajdy tworzyli: ks. Stanisław Smoleński, o. Karol Meissner OSB, ks. Tadeusz Ślipko SI, ks. Juliusz Turowicz ${ }^{4}$. Jako owoc pracy zespołu powstały dwa dokumenty wysoko ocenione przez papieża Pawła VI: Memoriał na temat problematyki moralnej dotyczącej małżeństwa oraz Komentarz do Encykliki Humanae vitae.

Do innych, bardziej szczegółowych kwestii podejmowanych przez Księdza Profesora należały następujące zagadnienia:

3 J. Bajda, Rodzina miejscem Boga i człowieka. Wokół zagadnień integralnego powołania rodziny, tomianki 2005, s. 26-27.

4 Por. K. Wojtyła, Komentarz teologiczno-duszpasterski do „Humanae vitae”, Rzym 1969, s. 4. 
- Osoba jako podmiot powołania (tematyka rozwijana głównie w ramach konwersatoriów na tematy antropologiczno-etyczne w Instytucie Jana Pawła II KUL);

- Koncepcja antropologiczno-etyczna małżeństwa i rodziny (z uwzględnieniem przesłanek teologicznobiblijnych nadających powołaniu małżeńskiemu i rodzinnemu właściwy wymiar teologicznomoralny);

- Rodzicielstwo jako temat wymagający szczególnego pogłębienia w kontekście powołania małżeńskiego (m.in. uściślenie idei odpowiedzialnego rodzicielstwa, zdefiniowanie moralnego statusu aktu małżeńskiego oraz etyczna kwalifikacja antykoncepcji i szerzej pojętych działań anty rodzicielskich);

- Zaawansowane próby syntezy na temat powołania rodzicielskiego oraz na temat teologiczno-etycznej struktury cnoty czystości;

- Nowych tematówdo badań dostarczyło nauczanie Jana Pawła II, które pogłębiło zarysowaną już na Soborze wizję integralnego powołania rodziny, szczególnie przez ukazanie ścisłej więzi między powołaniem rodziny a historią ludzkości oraz między kulturą a etycznym pojmowaniem życia osoby i wspólnoty osób („komunii osób”). Badania te znalazły wyraz w szeregu opracowań analizujących relację między etosem rodziny a kulturą ${ }^{5}$.

\section{Dorobek naukowy}

Dorobek naukowy ks. prof. Jerzego Bajdy obejmuje ponad 200 rozpraw, artykułów naukowych i popularnonaukowych. Do szczególnie ważnych publikacji należą:

1. Wprowadzenie do encykliki „Humanae vitae” (współautor), „Notificationes e Curia Metropolitana Cracoviensi” (1969) nr 1-4, tłum. wł. Introduzione all'enciclica Humanae vitae, Vatican 1969.

2. Les fondements de la doctrine de l'Eglise concernant les principes de la vie conjugale (współautor), „Analecta Cracoviensia” I (1969), s. 194-230.

5 Działalność naukowo-dydaktyczna Instytutu Studiów nad Rodzinq ATK 197 5-1998, red. K. Wolski, Łomianki 1999. 
3. Powołanie małżeństwa i rodziny, [w:] Teologia małżeństwa i rodziny, t. 1, red. K. Majdański, Warszawa 1980, s. 7-156.

4. Powołanie chrześcijańskie jako zasada teologii moralnej, Warszawa 1984.

5. Moralna ocena antykoncepcji a przerywanie ciąży, Gdańsk 1996.

6. Rodzina miejscem Boga i człowieka. Wokół zagadnień integralnego powołania rodziny, Łomianki 2005.

7. Powołanie małżenstwa i rodziny, Łomianki 2010

W Instytucie Studiów nad Rodziną w Łomiankach Ksiądz Profesor prowadził wykłady z zakresu integralnego powołania małżeństwa i rodziny, podstaw etyki płciowej, podstaw etyki małżeńskiej oraz podstaw etyki rodzicielskiej. Był promotorem ponad stu prac magisterskich, przygotował trzy razy tyle recenzji oraz wypromował kilkunastu doktorów, a także inspirował i wspierał cennymi konsultacjami prace habilitacyjne i profesorskie.

\section{Sylwetka Profesora}

Styl uprawiania nauki przez Księdza Profesora można by określić jako pokorny i odważny: widziałem w nim realizację zasady głoszonej przez papieża Benedykta XVI: Uczony jest sługą prawdy, a nie twórcą prawdy.

Jako wybitny sługa prawdy ks. prof. Jerzy Bajda znakomicie rozpoznawał pułapki subiektywizmu i relatywizmu, zwłaszcza w odniesieniu do życia małżeńskiego. Ponadto w sposobie ukazywania prawdy nigdy nie próbował pozyskiwać słuchaczy jakimiś atrakcyjnymi sformułowaniami, dobieraniem rodzaju wystąienia do aktualnych preferencji słuchaczy. Był rozmiłowany w prawdzie nie tylko na etapie badań, ale również na etapie przekazu, obdarzając wielkim szacunkiem słuchacza, którego nie tyle usiłował przekonywać błyskotliwymi ujęciami, ile starannością i rzetelnością argumentów zaczerpniętych z jak najgłębiej umotywowanej nauki moralnej i nauczania Kościoła. Oczywiście, stosował różne sposoby. Publikował artykuły nie tylko ściśle naukowe i opracowania monograficzne, ale także publicystyczne, pisał również bardzo dużo listów do poszczególnych rodzin.

Ksiądz Jerzy miał w sobie zawsze ogromny spokój. W codziennym kontakcie był bardzo serdeczny i potrafił znaleźć czas dla każdego, kto potrzebował 
z nim rozmowy, znajdując dobre słowo i radę. Niezwykle cierpliwy i zatroskany o dobro człowieka. Chętnie pomagał studentom i włączał się w ich inicjatywy integrujące środowisko oraz w akcje społeczne broniące lub promujące prawdziwe dobro rodziny. Taki był również dla kolegów - pracowników Instytutu, a szczególnie dla małżeństw i rodzin, którym służył radą i pomocą.

Będąc człowiekiem wielkiej wiedzy i mądrości, zachwycał skromnością i prostotą. W każdym zauważał dobro. Ks. prof. Jerzy Bajda był bezkompromisowy w uświadamianiu fałszu modnych ideologii oraz niezwykle czujny; ukazywał możliwe zagrożenia tkwiące zarówno w pojawiających się trendach kulturowych, jak i decyzjach rządzących, które dotyczyły spraw polityki rodzinnej i społecznej. Dlatego odrębny i pokaźny dział jego twórczości stanowi działalność publicystyczna, wypowiadał się nie tylko w artykułach, ale również w listach otwartych na temat różnych pomysłów, które oceniał jako niszczące naród i ojczyznę.

Ksiądz Profesor potrafił jednak zachować merytoryczny umiar i spokój wobec wszystkiego, co we współczesnym, coraz bardziej wirtualnym świecie, pochłania człowieka. Bez wątpienia osiągał to dzięki głębokiej relacji z Panem Bogiem, co owocowało również niezwykłą umiejętnością dzielenia się mocą Słowa Bożego, któremu ofiarnie i wiernie posługiwał podczas rekolekcji, dni skupienia, a także codziennych Eucharystii dla studentów i rodzin.

Do końca czuł się związany ze środowiskiem Instytutu - obecnie Wydziału Studiów nad Rodziną UKSW. Mimo przejścia na emeryturę, póki mu siły pozwalały, prowadził wykłady w Łomiankach.

\section{Zakończenie}

Miałem zaszczyt pożegnać Księdza Profesora Jerzego Bajdę w imieniu władz Wydziału w jego rodzinnym mieście - Bochni - następującymi słowami:

„Przyszedłem na świat, aby dać świadectwo Prawdzie” (J 18, 37).

Czcigodny i Kochany Księże Profesorze!

Najserdeczniej Ci dziękuję, że tak wiernie i hojnie oddałeś uczelni katolickiej prawie czterdzieści lat swojego życia, z tego trzydzieści lat Instytutowi Studiów nad Rodziną, dla którego byłeś i pozostaniesz świadkiem prawdy 
o małżeństwie i rodzinie, jednym z najbardziej twórczych filarów odkrywania tej prawdy!

Dziękujemy Opatrzności Bożej, że spotkaliśmy Ciebie, tak pięknego Człowieka - prostego, ubogiego, obdarzającego dobrocią i przyjaźnią, tak rozmiłowanego w Chrystusie - Kapłana, który swoim życiem i słowem wytrwale prowadził do Niego, tak kochającego Ojczyznę Polaka, wiernie troszczącego się o jej dobro i ostrzegającego przed zagrożeniami.

Dziękujemy Odwiecznej Prawdzie że spotkaliśmy Ciebie, tak bezpretensjonalnego i bezinteresownego człowieka nauki, a zarazem wybitnego polskiego teologa moralistę, uczącego nas rzetelnej, cichej i wytrwałej pracy naukowej, promotora otwartego na każdego studenta i recenzenta wielu prac doktorskich, magisterskich, inspirującego i wspierającego wielu naukowców na ścieżkach własnych samodzielnych prac habilitacyjnych i profesorskich.

A nade wszystko dziękujemy Rodzinie Świętej, że spotkaliśmy Ciebie, Świadka Prawdy, miłującego rodzinę i broniącego Bożej Prawdy o niej, oddanego do ostatniego tchnienia swojego życia sprawie obrony wartości i godności każdego ludzkiego życia.

Niech cie przygarnie Chrystus uwielbiony,

On wezwał ciebie do Królestwa światła.

Królestwa Prawdy i Miłości, i Wiecznego Życia.

Wspieraj nas, kochany Księże Profesorze,

byśmy wytrwali tak jak ty, do końca wierni Prawdzie miłujacej człowieka! 